\title{
Hidradenitis Suppurativa is a Diagnosis to be Discussed
}

\author{
Gregor B.E. Jemec \\ Department of Dermatology, Zealand University Hospital, Health Sciences Faculty, \\ University of Copenhagen, Roskilde, Denmark
}

\section{Keywords}

Case report $\cdot$ Hidradenitis suppurativa $\cdot$ Communication $\cdot$ Bibliometrics

\begin{abstract}
One of the values of case reports is that they foster communication between the involved parties. The cases included in this mini-review all underline different aspects of communication: between peers but also between physicians and patients. Few things, if any, can equal the concrete occasion to discuss empirical data. Among physicians, communication can not only create awareness but just as importantly provide solutions or suggest perspective to problems, while communication with patients is at the very core of medicine. These aspects are demonstrated in four cases dealing with the disease hidradenitis suppurativa.
\end{abstract}

(C) 2018 The Author(s)

Published by S. Karger AG, Basel

Hidradenitis suppurativa (HS) has been termed a "heart sink" condition for patients and physicians alike, meaning a disease that makes your heart sink [1]. For patients, the sensation is easily explained by the symptomatology and stigma associated with the disease [2,3]. It is one of the skin diseases most detrimental to patients' health-related quality of life [4]. Not only does the disease cause major symptoms such as pain and itch, it is also associated with many clinically significant comorbidities. Studies have shown an association with a large number of 
other diseases and symptoms, associations which naturally require an interdisciplinary approach, e.g., rheumatological symptoms [5]. The case report by Schneber et al. [6] clearly shows the utility of a multidisciplinary approach to patients with HS. In this case, the correct recognition of HS-associated pain helped the patient to a more appropriate therapy and avoided potentially complicated orthopedic spinal surgery.

Not all patients are, however, so lucky. HS is still associated with clinically highly significant comorbidities such as increased overall mortality and suicide [7, 8]. A rare cause of death in HS patients is HS-associated squamous cell carcinoma, which appears as Marjolin's ulcers typically in long-standing untreated lesions [9]. Increased awareness among all physicians and regular communication with the patients are rational measures. These may, however, be difficult to achieve in a busy practice, and the case by Pagliarello and Paradisi [9] is therefore a timely reminder of the physicians' most valuable collaborators: the patients. If patients are not educated to be aware of signs and symptoms of potential complications, complications can go unchecked with fatal consequences.

For physicians, the "heart sink" is being alleviated by more and more data of an increasing quality. After initial case reports of the benefits of new treatments, large trials have been carried out [10-12]. It is pleasing that these confirm the initial cases presented and therefore offer many patients hope for better control of their disease. Guidelines have been established both nationally, e.g., in Switzerland and Germany [13, 14], as well as internationally [15]. In spite of these improvements, patients still experience an unmet need for treatment, and so cases remain a valuable source of new ideas [16]. Cases may hold a low rank in the hierarchy of evidence-based medicine, but in the creation of knowledge they form the indispensable roots of renewal based not on the full understanding of the pathogenesis, but on the observation and detailed description of possibly causally related empirical phenomena.

Only by communicating do we ensure that our patients receive the continued dynamic assistance they need and that dermatology evolves.

\section{Disclosure Statement}

The author received honoraria from AbbVie, Janssen-Cilag, Novartis, Leo pharma, Pierre Fabre, and UCB for participation on advisory boards, and grants from Abbvie, InflRx, JanssenCilag, Leo Pharma, Novartis, Regeneron and Serono for participation as an investigator, and received speaker honoraria from AbbVie, Galderma, Leo Pharma, and MSD. He has furthermore received unrestricted research grants from AbbVie, Leo Pharma and Novartis.

\section{References}

1 von der Werth JM, Williams HC. The natural history of hidradenitis suppurativa. J Eur Acad Dermatol Venereol. 2000 Sep;14(5):389-92.

2 Jemec GB. Clinical practice. Hidradenitis suppurativa. N Engl J Med. 2012 Jan 12;366(2):158-64.

3 Matusiak L, Bieniek A, Szepietowski JC. Psychophysical aspects of hidradenitis suppurativa. Acta Derm Venereol. 2010 May;90(3):264-8.

4 Alavi A, Anooshirvani N, Kim WB, Coutts P, Sibbald RG. Quality-of-life impairment in patients with hidradenitis suppurativa: a Canadian study. Am J Clin Dermatol. 2015 Feb;16(1):61-5.

5 Rondags A, Arends S, Wink FR, Horváth B, Spoorenberg A. High prevalence of hidradenitis suppurativa symptoms in axial spondyloarthritis patients: A possible new extra-articular manifestation. Semin Arthritis Rheum. 2018 Mar 20. pii: S0049-0172(18)30015-5.

6 Schnebert B, Del Marmol V, Benhadou F. Low Back Pain in Hidradenitis Suppurativa: A Diagnosis Not to Miss! Case Rep Dermatol. 2018 Jul 12;10(2):187-9. 
7 Egeberg A, Gislason GH, Hansen PR. Risk of Major Adverse Cardiovascular Events and All-Cause Mortality in Patients With Hidradenitis Suppurativa. JAMA Dermatol. 2016 Apr;152(4):429-34.

8 Thorlacius L, Cohen AD, Gislason GH, Jemec GB, Egeberg A. Increased Suicide Risk in Patients with Hidradenitis Suppurativa. J Invest Dermatol. 2018 Jan;138(1):52-7.

9 Pagliarello C, Paradisi A. The perils of a defective medical communication: fatal neglected squamous cell carcinoma arising in perineal hidradenitis suppurativa. Case Rep Dermatol. 2011 Jan;3(1):5-7.

10 Gorovoy I, Berghoff A, Ferris L. Successful Treatment of Recalcitrant Hidradenitis Suppurativa with Adalimumab. Case Rep Dermatol. 2009 Oct;1(1):71-7.

11 Kimball AB, Kerdel F, Adams D, Mrowietz U, Gelfand JM, Gniadecki R, et al. Adalimumab for the treatment of moderate to severe Hidradenitis suppurativa: a parallel randomized trial. Ann Intern Med. 2012 Dec;157(12):846-55.

12 Kimball AB, Okun MM, Williams DA, Gottlieb AB, Papp KA, Zouboulis CC, et al. Two Phase 3 Trials of Adalimumab for Hidradenitis Suppurativa. N Engl J Med. 2016 Aug;375(5):422-34.

13 Hunger RE, Laffitte E, Läuchli S, Mainetti C, Mühlstädt M, Schiller P, et al. Swiss Practice Recommendations for the Management of Hidradenitis Suppurativa/Acne Inversa. Dermatology. 2017;233(2-3):113-9.

14 Zouboulis CC, Bechara FG, Fritz K, Kurzen H, Liakou AI, Marsch WC, et al; Deutsche Dermatologische Gesellschaft; Berufsverband Deutscher Dermatologen; Deutsche Gesellschaft fur Koloproktologie; Deutsche Gesellschaft fur Dermatochirugie; Hidradenitis Suppurativa Foundation; Deutsche Interessegemeinschaft Akne inversa; Deutsche Gesellschaft fur Psychosomatische Medizin; European Society of Dermatology and Psychiatry; European Society of Laser Dermatology. [S1 guideline for the treatment of hidradenitis suppurativa / acne inversa * (number ICD-10 L73.2)]. J Dtsch Dermatol Ges. 2012 Oct;10 Suppl 5:S1-31.

15 Zouboulis CC, Desai N, Emtestam L, Hunger RE, Ioannides D, Juhász I, et al. European S1 guideline for the treatment of hidradenitis suppurativa/acne inversa. J Eur Acad Dermatol Venereol. 2015 Apr;29(4):619-44.

16 Khandalavala BN. A Disease-Modifying Approach for Advanced Hidradenitis Suppurativa (Regimen with Metformin, Liraglutide, Dapsone, and Finasteride): A Case Report. Case Rep Dermatol. 2017 Jul;9(2):70-8. 